\title{
"KISSING MOLARS" - TERCEIRO E QUARTO MOLARES RETIDOS EM REGIÃO DE MANDIBULA ASSOCIADO À CISTO DENTÍGERO
}

Fernando Koga SAKURAI, Eduardo MORESCHI, Renato ZARDETTO, Vilmar GOTTARDO, Ana Regina CASAROTO

Os dentes supranumerários correspondem aos dentes formados em maior número que os da série normal. Podem ocorrer de forma isolada ou em multiplicidade, unilateral ou bilateralmente, na maxila, mandíbula ou em ambos os arcos, podendo ser de morfologia típica ou atípica e ainda acometer a dentição decídua ou permanente. Podem ser detectados pelo exame físico intra-bucal quando irrompidos, através de exames radiográficos de rotina quando não-irrompidos. O tratamento a ser instituído é dependente de cada caso, no entanto, na maioria das vezes é cirúrgico visto que esses dentes podem acarretar complicações como distúrbio no irrompimento de dentes da série normal, diastemas, reabsorções radiculares, lesões císticas, máoclusão e outras. O presente trabalho teve como propósito descrever radiograficamente e clinicamente um caso de terceiro e quarto molar inferior retido em posição atípica, associado a cisto dentígero, em uma paciente do gênero feminino, 32 anos, leocoderma, descritos na literatura como "kissing molars". O tratamento por indicação ortodôntica foi cirúrgico com a remoção também do terceiro molar.

Palavras-chave: cisto dentígero, dentes supranumerários, "kissing molars". 